\title{
'Le sottili cose non si possono bene aprire in volgare': Vernacular Oratory and the Transmission of Classical Rhetorical Theory in the Late Medieval Italian Communes
}

\author{
Stephen J. Milner \\ University of Manchester
}

The renaissance of interest in classical rhetoric in late medieval Italian literary culture stands at the heart of many accounts of the origins of humanism as an educational programme and set of critical practices. This article, however, seeks to examine the spoken rather than the written word and the vernacular rather than Latin transmission of speechmaking knowhow in the Due- and Trecento, with particular attention paid to the social and political contexts of the rhetorical revival. The aim is to move beyond some of the more narrowly configured definitions of rhetorical humanism and demonstrate how the increasing diffusion of rhetorical knowledge in the vernacular led to its democratization as translators and adapters 'opened' increasingly complex parts of rhetorical theory for a lay audience. Rather than delaying the onset of full-blown humanism, understood as an elite Latin-based enterprise, the vernacularization of rhetorical material functions as a keystone in the transmission of knowledge derived from classical culture for applied usage by a much wider social constituency.

KEYWORDS vernacular, rhetoric, speechmaking, commune, transmission

The quotation cited in the title is drawn from Bono Giamboni's redaction of the Fiore di rettorica, a vernacular abridgement of the pseudo-Ciceronian Rhetorica ad Herennium, otherwise known during the medieval period in Italy as the Rhetorica nova. Dated by Speroni, in his exhaustive and fine critical edition of the various redactions, to the mid-thirteenth century (c. I260), the work stands, together with Brunetto Latini's Rettorica and Trésor, squarely within the period that witnessed the first wave of the late medieval production of vernacular renditions, paraphrases, and 
florilegia of rhetorical material. Drawing from classical authors, this material furnished guidance to those seeking instruction in the rhetorical arts, most notably in Bologna and Florence. ${ }^{\mathrm{I}}$ These works have recently been the subject of renewed critical attention which has demonstrated the extent to which the Italian ars dictaminis and Ciceronian vernacular commentary tradition addressed the performative and consultative context of the late medieval Italian communes. ${ }^{2}$ However, Giamboni's claim that there were limits to those aspects of classical rhetorical doctrine that could be 'opened' into the vernacular is an interesting one. For on the one hand he seems to be suggesting that the difficulty was a linguistic one - that the more complex parts of rhetorical theory were difficult to render and exemplify in the volgare - while on the other hand he seems to be intimating, with typical patrician reserve, that 'sottili cose' were best set aside when addressing an uneducated (namely non-Latin literate) audience who he felt had no need for certain classical rhetorical precepts. ${ }^{3}$

In what follows, the aim is to map what became available, to whom, where and why, in order to account for the increasing dissemination and transmission of vernacular know-how concerning public speaking between the mid-Duecento and the late Trecento. By establishing more clearly the specific institutional and social contexts within which the growth of vernacular oratorical instruction and practice took place, the intention is to demonstrate how the late medieval vernacular public speaker secured oratorical competency. In part such a study necessarily becomes a history of the growth of non-Latin literate consumers of rhetorical advice and their periodic, and partial, accommodation both within and beyond programmes of formal instruction; for the vernacular, as an unstable language subject to local variation, was impossible to codify and therefore ill-suited to the teaching of a formal art such as rhetoric, the official language of instruction in all arts being Latin. ${ }^{4}$ Obviously the

I Bono Giamboni, Fiore di rettorica, ed. by Giambattista Speroni (Pavia: Università di Pavia, I994). John O. Ward, Ciceronian Rhetoric in Treatise, Scholion and Commentary, Typologie des Sources du Moyen Âge Occidental, 58 (Turnhout: Brepols, 1995) is an indispensable guide to the continuity of the Ciceronian rhetorical tradition in the Middle Ages.

2 See the essays in The Rhetoric of Cicero in its Medieval and Early Renaissance Commentary Tradition, ed. by Virginia Cox and John O. Ward (Leiden: Brill, 2006), especially Virginia Cox, 'Ciceronian Rhetoric in LateMedieval Italy: The Latin and Vernacular Traditions', pp. I09-43 and Stephen J. Milner, 'Communication, Consensus and Conflict: Rhetorical Precepts, The ars concionandi and Social Ordering in Late Medieval Italy', pp. 365-408, and the essays collected in Papers on Rhetoric V: atti del convegno internazionale " Dictamen", "poetria" and Cicero: Coherence and Diversification', Bologna, IO-II maggio 2002, ed. by Lucia Calboli Montefusco (Rome: Herder, 2003).

3 For an overview of the concept of 'sottigliezza' as found in poetic, literary, and rhetorical texts of the period see Francesco Bruni, 'Semantica della sottigliezza', in Testi e chierici del medioevo (Genoa: Marietti, I99I), pp. 9I-I33. For its use within a legal, Bolognese setting, see Claudio Sanchez-Albornoz, 'Appunti per un commento alle Quaestiones de iuris subtilitatibus (“Exordium”)', in Estudios en homenaje a don Claudio Sánchez Albornoz en sus 90 años, ed. by Maria del Carmen Carle, 6 vols (Buenos Aires: Instituto de Historia de España, I985), III, 3-58.

4 See Robert Black, Humanism and Education in Medieval and Renaissance Italy: Tradition and Innovation in Latin Schools from the Twelfth to the Fifteenth Century (Cambridge: Cambridge University Press, 200I) and Paul F. Gehl, A Moral Art: Grammar, Society, and Culture in Trecento Florence (Ithaca: Cornell University Press, 1993). Gehl argues that the conservatism of Latin grammar education in Trecento Florence reacted to the growing vernacular culture and nascent humanism by restricting the Latin curriculum even further. On Latin as the language of pedagogy see Silvia Rizzo, 'Petrarca, il latino, e il volgare', Quaderni petrarcheschi, 7 (I990), 7-40. 
vernacular was used and a shared koiné permitted communication notwithstanding dialect variations, but it was not taught within schools or on higher level courses. ${ }^{5}$ An examination of the translation processes of classical rhetorical theory, therefore, offers the possibility of examining which 'flowers of rhetoric' vernacular translators and commentators thought worth picking; how such vernacular guidance concerning oratory related to formal Latin-based instruction in matters rhetorical; and the relative weighting granted to doctrinal instruction and exemplary illustration in fashioning public speakers.

In pursuing such an undertaking, the aim is also to question further the characterization of medieval rhetoric as a fractured and incoherent shadow of its classical predecessor. ${ }^{6}$ Rather than chiding its perceived shortcomings relative to its classical source, the intention is to examine the extremely dynamic and creative processes of adaptation and appropriation whereby late medieval consumers made active choices and customized the classical rhetorical material available to them. By examining what they took up and what they chose to leave behind as they transplanted and translated classical material to their own social landscapes, it should be possible to throw further light on their civic needs and rhetoric's situated use. We can then move towards a more nuanced account of the renaissance of interest in classical rhetoric and its perceived applicability to a range of potential users who were interested in developing a set of dispositions and skills in reciprocal relation to a past culture. Recently it has been argued that the late medieval explosion in the volgarizzamento of classical authors, especially in Tuscany, set back the advent of full-blown humanism as found in the Latin writings of figures such as Coluccio Salutati and Leonardo Bruni, humanistic classicism arriving in Italy through the agency of poetry rather than oratory. ${ }^{7}$ Through examining the late medieval reception of classical rhetorical theory it may be possible to question such definitions of the scope and origins of rhetorical humanism by focusing specifically on the role played by the discerning acts of cultural adaptation and appropriation undertaken within the medieval Italian communal context. ${ }^{8}$

\section{The emerging market}

There is no doubting the demand within the Italian communes for vernacular advice on the effective management of speech. One gauge for measuring such a market is

5 Nigel Vincent, 'Languages in Contact in Medieval Italy', in Rethinking Languages in Contact: The Case of Italian, ed. by Anna Laura Lepschy and Arturo Tosi (Oxford: Legenda, 2006), pp. I2-27.

6 See, for example, the two chapters in Brian Vickers, In Defence of Rhetoric (Oxford: Clarendon Press, I988), pp. 2I4-93: 'Medieval Fragmentation' and 'Renaissance Reintegration'. On the 'failure' of the Middle Ages to produce a readily identifiable ars rhetorica see Richard McKeon, 'Rhetoric in the Middle Ages', Speculum, I7 (I942), I-32.

7 'The precociousness of vernacular literature in Florence, which was directly related to a widespread vernacular literacy, in the short run hindered the development of humanism in Florence', Ronald G. Witt, In the Footsteps of the Ancients: The Origins of Humanism from Lovato to Bruni (Leiden: Brill, 2000), p. 229. For a discussion of Witt's thesis see Robert Black, 'The Origins of Humanism. Its Educational Contexts and Its Early Development: A Review Article of Ronald Witt's In the Footsteps of the Ancients', Vivarium, 40 (2002), $272-97$.

8 For a discussion of this branch of reception studies see Julie Sanders, Adaptation and Appropriation (London: Routledge, 2006). 
the speed with which texts were translated into the volgare, often by the authors themselves. Latini's Trésor, for example, was translated from the French within the same six-year span as the original text's composition, whilst Albertano da Brescia's Liber de doctrina dicendi et tacendi of $\mathrm{I} 245$ was soon available in two vernacular versions which circulated widely: the first by Andrea da Grosseto in I 268 and the second Pistoiese version by Soffredi del Grazi in I278. ${ }^{9}$ Another indicator of demand is the sheer complexity of the various redactions, compilations, collations, and paraphrases of this material that defy all but the most determined attempts at systematic attribution, codification, or dating. In a rhetorical transmission culture that privileged piecemeal selection based on availability and utility at a time when other genres of writing were beginning to foreground the function of the auctor over that of the compilator, Albertano's corpus is actually an exception rather than the rule. ${ }^{\text {IO }}$ The principal catalysts for the beginning of the vernacularization of rhetorically related material were twofold: firstly, the need to address social and ritual situations which demanded the use of the vernacular, for example in addressing public gatherings, large civic councils, or parlamenti, and subsequently, to meet the demand for rhetorical guidance on the part of a social constituency with little or no knowledge of Latin - the so-called illetterati. ${ }^{\text {II }}$

In this sense, the demand for rhetorical advice concerning the spoken word was a contributory factor in establishing the vernacular as writable. For the emergence of what Petrucci has termed the 'free literates' within communal scribal culture and the growing levels of lay literacy was accompanied by a commensurate opening up of the oral realm to an identical social constituency. In medieval Italy, therefore, the differentiation between precept and performance was often as much a difference of language as it was a difference of place. The vernacular speechmaking which took place in the councils and piazzas of the medieval communes provided the closest cultural parallel to the original social geography of classical rhetorical performance. Consequently the history of the transmission of vernacular speechmaking know-how is also a history of the acknowledgement on the part of those trained in Latin of the civic requirement to address their fellow citizens in their native tongue. Such occasions became increasingly common within the everyday life of the typical

9 On Latini's vernacular Tesoro see Paolo Dovizia, 'Aggiunte (e una sottrazione) al censimento dei codici delle versioni italiane del Trésor di Brunetto Latini’, Medioevo Romanzo, 32 (2008), 377-94, and Carla Mascheroni, 'I codici del volgarizzamento italiano del Trésor di Brunetto Latini', Aevum, 43 (I969), 485-5Io. On Albertano see the useful website run by Angus Graham: <http://freespace.virgin.net/angus.graham/Albertano.htm> [accessed 24 August 2009].

Io See the seminal study by Gianfranco Folena, Volgarizzare e tradurre (Turin: Einaudi, I99I); Francesco Bruni, 'Il volgare nel periodo delle origini', in L'italiano: elementi di storia della lingua e della cultura. Testi e documenti (Turin: UTET, I984), pp. 3-35; and Cesare Segre, 'La traduzione come fenomeno culturale. Primi secoli', in Il volgare come lingua di cultura dal Trecento al Cinquecento. Atti del convegno internazionale, Mantova, I8-20 ottobre 200I, ed. by Arturo Calzona, Francesco Paolo Fiore, and others (Florence: Olschki, 2003), pp. I-8.

${ }^{\text {II }}$ See Attilio Bartoli Langeli, Storia dell'alfabetismo come storia degli scriventi: gli usi della scrittura in Italia tra medioevo ed età moderna (Florence: Università di Firenze, I989), pp. 8-10 and H. Grundmann, 'Litteratus-illiteratus', Archiv für Kulturgeschichte, 40 (I958), I-65. 
commune in which vernacular speechmaking was clearly an activity undertaken by a growing number of people. ${ }^{\mathrm{I} 2}$

The combining of Latin instruction and vernacular exemplification was a characteristic of writings that addressed public oratory. By contrast, the vast majority of instruction and exemplification available for its scribal sister, the ars dictaminis, was in Latin, the assumption being that anybody undertaking formal training at university level was Latin literate. ${ }^{13}$ That many practitioners of the ars dictaminis referred to themselves during this period as rhetorici was mainly due to the fact that almost all the theoretical underpinning of the ars dictaminis was drawn from the De inventione and Rhetorica ad Herennium, the model of a well-constructed letter, consisting of the salutatio, exordium, narratio, petitio, and conclusio, being premised on the six-part Ciceronian oration. ${ }^{\mathrm{I}}{ }^{\mathrm{I}}$ In fact the letter was often defined as a surrogate for face-to-face dialogue in a manner which questions the overly prescriptive critical differentiation often made between the primary rhetoric of speech and the secondary rhetoric of prose. ${ }^{15}$ Consequently many letters, as semi-public documents, were actually read out by ambassadors, emissaries, or other officials with mandates from their communes. ${ }^{16}$ Guidance within dictamina relating to delivery and pronunciation, therefore, clearly points to this practice of reading letters out loud in assemblies with many dictatores referring to the intended recipient as an auditor rather than a lector. ${ }^{17}$ The championing of the stilus humilis by the likes of Boncompagno da Signa (c. II70-I240s) and Guido Fava (c. II90-c. I243) in Bologna was directly linked to this need for letters to be understood easily when read out, or at least on a second reading. ${ }^{18}$

${ }^{\text {I2 }}$ On the emergence of this new communal audience for rhetorical guidance and vernacular works see F. Cardini, 'Alfabetismo e livelli di cultura nell'età comunale', Quaderni storici, I3 (1978), 488-522 and Armando Petrucci, Writers and Readers in Medieval Italy: Studies in the History of Written Culture, ed. and trans. by Charles M. Radding (New Haven: Yale University Press, I995), pp. 169-235. For surveys of texts which dealt with the spoken word see the foundational studies of Enrico Artifoni, especially 'I podesta professionali e la fondazione retorica della politica comunale', Quaderni storici, 63 (I986), 687-7I9 and 'Gli uomini dell'assemblea. L'oratoria civile, i concionatori e i predicatori nella società comunale', in La predicazione dei frati dalla metà del '200 alla fine del '300. Atti del XXII convegno internazionale. Assisi, I3-I5 ottobre I994 (Spoleto: Centro italiano di studi sull'alto medioevo, I995), pp. I43-88.

${ }^{13}$ See Malcolm Richardson, 'The Ars dictaminis, the Formulary, and Medieval Epistolary Practice', in LetterWriting Manuals and Instruction from Antiquity to the Present, ed. by Carol Poster and Linda C. Mitchell (Columbia: University of South Carolina Press, 2007), pp. 52-66 and Ward, Ciceronian Rhetoric, pp. 62-66.

${ }^{\mathrm{I}} 4 \mathrm{On}$ the debt of the ars dictaminis to Cicero see Martin Camargo, Ars dictaminis Ars dictandi, Typologie des Sources du Moyen Âge Occidental, 60 (Turnhout: Brepols, I99I), pp. I9-28 and John O. Ward, 'Rhetoric and the Art of Dictamen', in Études sur le vocabulaire intellectuel du moyen age III, ed. by Olga Weijers (Turnhout: Brepols, I990), pp. 20-6I.

${ }^{15}$ For a critique of this distinction see Marjorie Curry Woods, 'The Teaching of Writing in Medieval Europe', in A Short History of Writing Instruction from Ancient Greece to Twentieth-Century America, ed. by James J. Murphy (Davis: Hermagoras Press, I990), pp. 77-94.

${ }^{16}$ See C. D. Lanham, 'Salutatio' Formulas in Latin Letters to I200: Syntax, Style, and Theory (Munich: Wipf and Stock, I975), pp. I03-O4 and Giles Constable, Letters and Letter-Collections, Typologie des Sources du Moyen Âge Occidental, I7 (Turnhout: Brepols, I976), pp. I3-I5.

${ }^{17}$ See, for example, the section on pronunciation in Jacques de Dinant's Summa dictaminis in A Textual Study of Jacques de Dinant's 'Summa dictaminis', ed. by Emil J. Polak (Geneva: Librairie Droz, 1975), pp. 70-73, and Camargo, Ars dictaminis, p. 25.

${ }^{18}$ Boncompagno in his Palma of II98 [26. 5] remarked that 'omnia in stilo epistolari debeant ita esse lucida et aperta, quod in prima vel secunda prolatione audientes intelligere possint' [everything in the epistolary style should be clear and open so that the listener can understand at the first or second reading]. See Ronald G. Witt, 'Boncompagno and the Defence of Rhetoric', Journal of Medieval and Renaissance Studies, I6 (I986), I-3I (p. 9). 
Placed within a civic context, therefore, the primary function of dictaminal instruction was diplomatic and administrative, and the pedagogical tracts were clearly intended for trainee notaries who had already undergone training, and were competent in Latin and destined to work as letter writers and producers of official documents within communal, imperial, and papal chanceries. However, the parallels between the brief of the ars dictaminis and the requirements of orators should not overshadow the considerable differences. The relative neglect of invention, memory, and delivery by the dictatores and the prominence granted to the petitio and salutatio clearly identify their communicative priorities and clearly did not meet the brief in terms of furnishing instruction for public speaking. ${ }^{\text {.9 }}$

\section{Boncompagno's rhetoric of law}

A convenient and appropriate point of departure for the study of rhetorical culture is medieval Bologna, combining as it did both educational and political contexts in its guise as a university city and a self-determining commune. In many respects the history of rhetorical instruction within the city can be charted through the antagonism and collaboration between these two sectors. Early evidence suggests that vernacular speechmaking was not considered a skill worthy of formal instruction, the contempt for popular vernacular oratory amongst the legal elite being apparent in the comments of Boncompagno da Signa when delivering his Rhetorica novissima (I235) to a university audience in Bologna. Identifying the emergence of free communes in Italy as the catalyst for popular oratory, he famously remarked that 'verum quia contionandi officium rarissime ad viros pertinet litteratos, idcirco hec plebia doctrina est laicis Italie reliquenda, qui ad narrandum magnalia contionum a sola consuetudine sunt instructi' [the true duty of speechmaking rarely pertains to literate men, and consequently this base art is to be left to the laymen of Italy, who, in giving their grandiloquent speeches, are instructed by custom alone]. ${ }^{20}$ Boncompagno was referring here to vernacular speechmaking and his disdain derived from the fact that popular speechmaking was, in his eyes, not an art but 'merely' a practice. In explaining the need for a 'newer' rhetoric, Boncompagno noted the only benefit to law students in studying rhetoric in the liberal arts programme was to gain instruction in speechmaking, a sphere of competency he clearly saw as falling outside his perceived remit. ${ }^{2 \mathrm{I}} \mathrm{His}$ own tract did include extensive exemplary speech material relating to

I9 See the comments of M. Camargo, 'Where's the Brief? The Ars dictaminis and Reading/Writing Between the Lines', Disputatio, I (I996), I-I7.

${ }^{20}$ Boncompagni da Signa, Rhetorica novissima, ed. by Augusto Gaudenzi, Bibliotheca Iuridica Medii Aevi, 3 vols (Bologna: Piero Virano, I892), II, 249-97: I3. I. II 'De moribus contionatorum'. In his Boncompagnus (c. I215), also known as the Rhetorica antiqua, Boncompagno argues that formal instruction in rhetorical doctrine is to be preferred to the many useless precepts often passed on by orators. See Boncompagno da Signa, Boncompagnus, in Ludwig von Rockinger, Briefsteller und Formelbücher des elften bis vierzehnten Jahrhunderts (Munich: I863-64 repr. New York: B. Franklin, I961), p. I29.

${ }^{21}$ The second of the three reasons given for writing his text is cited as follows: 'Secunda fuit quia studentes in utroque iure modicum vel quasi nullum subsidium excepta sola contione habere poterant de liberalium artium disciplina' [The second reason was that students in both canon and civil law receive little or nothing [in terms of rhetorical training] from the liberal arts beyond public speaking]. See Boncompagni da Signa, Rhetorica novissima, prologue 6. 
model exordia and invectives, as well as advice on how to address a judge in terms of vocal production and gesture. ${ }^{22}$ In addition, his forensic focus required the furnishing of guidance on delivery, memory, and those aspects of classical rhetoric that generally received less attention within the more scripturally orientated tracts of the dictatores. ${ }^{23}$ However, Boncompagno's rhetorical instruction did not really extend beyond the courtroom and his advice only tangentially touched upon the other principal social contexts of public oratory addressed in classical rhetorical theory, the forum and deliberative assembly. ${ }^{24}$

This attitude was consistent with his well-known anti-Ciceronianism that manifested itself in his attempts to distance himself from his liberal arts peers by insisting upon the primacy of civil and canon law over rhetorical study. ${ }^{25}$ In fact, his use of rhetoric was as a source of topical invention within forensic argumentation. Indeed, until the mid-Trecento the Latin tradition of Ciceronian commentary on the Ad Herennium saw lawyers studying the text with a view to learning about invention in the composition of juridical narrationes in conjunction with such texts as Boethius' De topicis differentiis and commentaries on Cicero's Topica. In this context, we should not therefore assume that any classical precepts learnt as part of a law degree were easily transferred to an oratorical context, whether Latin or vernacular.

Boncompagno's positioning, therefore, accounts for the rather summary treatment of deliberative and demonstrative oratory in Books II-I3 of the Rhetorica novissima, which contain almost no rhetorical doctrine and refer the reader back to the lengthy Book 5 for information regarding the use of exordia. Instead, he offers a moralizing discussion of the virtues and vices to be followed and avoided in civic debate in Book II, 'De consiliis', and a satire of the speechmaking practices of contemporary public speakers in Book I3, 'De contionibus'. His comments concerning the obligations of such speechmakers are representative of his outlook: 'Officium contionatoris est adulari, interponere mendacia palliata et uti persuasionibus deceptivis' [The duty of the speechmaker is to flatter, cloak the use of lies, and introduce deceitful forms of persuasion]. ${ }^{26}$ In point of fact he showed no interest in the vernacular, and when

${ }^{22}$ Rhetorica novissima, 4. I: 'De naturis et consuetudinibus oratorum'; and 4. 2: 'De gestibus prolocutorum'. There is internal evidence within his other writings that he authored a separate tract on this subject: De gestibus et motibus corporum humanorum. See Boncompagnus, I. 4. 2 and De amicitia, 30. For Boncompagno's derisory assessment of the pronunciation of popular orators see the Rhetorica novissima, p. 294.

${ }^{23}$ On Boncompagno and memory see Mary Carruthers, 'Boncompagno at the Cutting-Edge of Rhetoric: Rhetorical Memoria and the Craft of Memory', Journal of Medieval Latin, 6 (I996), I44-64 and 'Boncompagno da Signa, On Memory', trans. by Sean Gallagher in The Medieval Craft of Memory: An Anthology of Texts and Pictures, ed. by Mary Carruthers and Jan M. Ziolkowski (Philadelphia: University of Pennsylvania Press, 2002), pp. IOI-I7.

${ }^{24}$ On Boncompagno's applied approach to rhetorical instruction, in both his dictaminal and oratorical writings see Witt, 'Boncompagno' and Terence O. Tunberg, 'What is Boncompagno's "Newest Rhetoric”?', Traditio, 42 (I986), 299-334.

${ }^{25}$ On Boncompagno's educational elitism see Enrico Artifoni, 'Boncompagno da Signa, i maestri di retorica e le città comunali nella prima metà del Duecento', in Il pensiero e l'opera di Boncompagno da Signa. Atti del primo convegno nazionale (Signa 23-24 febbraio 200I), ed. by Massimo Baldini (Greve in Chianti: Grevigiana, 2002), pp. 23-36. See also Francesco Bruni, 'Boncompagno da Signa, Guido delle Colonne, Jean de Meung: metamorfosi dei classici nel Duecento', in Retorica e poetica tra i secoli XII e XIV, ed. by Claudio Leonardi and Enrico Menestò (Perugia: La Nuova Italia, I988), pp. 79-Io8 (pp. 83-87).

${ }^{26}$ Rhetorica novissima, I3. I. 3: 'De officio contionatoris'. 
teachers like Boncompagno did speak in a formal context, their speeches were in Latin and normally addressed to students at the start of term or to their fellow professionals. $^{27}$

\section{From feudal to popular speech}

The need to address a non-Latin literate public in their own tongue was first acknowledged within tracts addressed to the class of itinerant executive magistrates who presided over the communal councils as podestà and capitani, responsible for public security, police matters, and the suppression of rebellions. Largely an invention of Frederick I, they appeared on the Italian political landscape between II5O and I200 as mediators between communal governments and the Emperor. ${ }^{28}$ In the first half of the Duecento it was the militaristic attributes of such officials that were considered of primary importance in their role as peacemakers and law enforcers. Mainly drawn from major dynastic families 'de genere militum', these officials were often legally trained and, due to their function, required to bring with them a 'famiglia' of staff including notaries, and canon and civil law judges. ${ }^{29}$

Giovanni da Viterbo, himself a judge or notary within such a podestarial 'famiglia', noted in his Liber de regimine civitatum of $c$. I234 the affinity between the authority of the podestà and the 'maestà imperiale', encouraging such officials to align themselves with the resident 'milites' of the communes over which they officiated. ${ }^{30}$ The earlier Oculus pastoralis of $c$. I222, which is the first recognizable collation of sample orations for public settings, was clearly written by an author addressing an identical social and political constituency, several orations being addressed to the Emperor and one to a commune accused of conspiring with the Emperor's enemies and encouraging neighbouring communes to revolt. ${ }^{3 \mathrm{I}}$ Unsurprisingly, neither tract seeks to educate a broader social constituency, yet both introduce vernacular elements into their works. In the incipit to his tract, Giovanni da Viterbo admits that such senior

${ }^{27}$ For orations given by teachers to students and colleagues see Guido Zaccagnini, 'Lettere ed orazioni di grammatici dei secc. XIII e XIV', Archivium romanicum, 7 (I923), 5I7-34.

${ }^{28}$ See Andrea Zorzi, 'La giustizia imperiale nell'Italia comunale' and Stefano Gasparri, 'Tradizioni imperiali e cavalleria. La ricezione nell'ambiente cittadino', in Federico II e le città italiane, ed. by Pierre Toubert and Agostino Paravicini Bagliani (Palermo: Sellerio editore, I994), pp. 85-103 and pp. 303-18.

29 See Vittorio Franchini, Saggio di ricerche sull'istituto del podestà nei comuni medievali (Bologna: Nicola Zanichelli, I9I2) and Daniela De Rosa, Alle origini della Repubblica fiorentina. Dai Consoli al 'Primo popolo' (II72-I260) (Florence: Arnaud, I995), pp. 97-I22.

$3^{\circ}$ On the podestarial class as a distinct social grouping which combined military, legal, and oratorical competencies and was clearly differentiated from the emerging popolo, see Jean-Claude Maire Vigueur, 'L'ufficiale forestiero', in Ceti, modelli, comportamenti nella società medievale (secoli XIII-metà XIV) (Pistoia: Centro italiano di studi di storia e d'arte, 200I), pp. 75-97. On Giovanni see Andrea Zorzi, 'Giovanni da Viterbo', Dizionario biografico degli italiani (Rome: Istituto della Enciclopedia Italiana, I960-), LVI (200I), 267-72.

${ }^{31}$ See 'Oculus pastoralis pascens officia et continens radium dulcibus pomis suis', ed. by D. Franceschi, Memorie dell'Accademia delle scienze di Torino, II (I966), 3-74 (p. 50): 'De responsione facta a mandato imperatoris', and Terence Owen Tunberg, 'Oculus pastoralis: An Edition', (unpublished doctoral thesis, University of Toronto, 1986). On the imperial theme within the text see Diego Quaglioni, 'Politica e diritto al tempo di Federico II. L'Oculus pastoralis (I222) e la "sapienza civile"', in Federico II e le nuove culture. Atti del XXXI convegno storico internazionale (Todi, 9-I2 ottobre 1994) (Spoleto: Centro italiano di studi sull'alto medioevo, I995), pp. 2-26. 
policing and political roles may be assumed by non-Latin literate officials who shared an equal right to honour and glory as rewards for their good stewardship over the community which granted them their authority: 'rudes vero et indoctos in eodem opusculo fideliter edoceri non pigeat, ut postmodum ipsius commodes peritia eruditi, ad regendum alios secure accedentes, de suo bono regimine consequantur commodum, gloriam et honorem' [It ought to be no cause for regret that the ignorant and unlearned are faithfully instructed in this same work, so that, having duly absorbed the lessons it contains, in undertaking without apprehension to rule over others, they may, by their good governance, secure advantage, honour, and glory]. ${ }^{32}$ Consequently his advice acknowledges the need to address such communities in both deliberative and demonstrative contexts, combining procedural advice and moralizing sententiae with a large number of exemplary models of both speeches and letters, which mix Latin and vernacular especially in their exordia. ${ }^{33}$ Although he lists eloquence and speechmaking ability as prerequisites for a good podestà, he advises those who felt ill-qualified to undertake such tasks to appoint judges as part of their entourage who were capable of acting as speechwriters. ${ }^{34}$

The author of the Oculus pastoralis alludes to the linguistic competency of his intended readership when noting his intention to couch his advice in a simple and clear style in order to render the examples accessible and useful to the 'moderately educated' layman:

In hoc oppuscolo quod rogatus quasi invitus agredior, stillo clariori et simplici dictamine fungar, quoniam simplicitas est amica laicis rudibus et modice literatis, ad utilitatem quorum, si qui quandoque ad locorum regimina sint asumpti, sequentia componuntur, ut ex eis aliqua subtili ingenio et sagaci prelibare valleant, quibus rectoriçent in subiectus et alios, cum ocurerit utilitas vel necessitas proponendi. ${ }^{35}$

The petitioner who requested the work was clearly expected to have the rudiments of Latin literacy in order to understand the text, the only concessions made for any difficulty with the language being stylistic and lexical ones. Although Latin guidance serves vernacular performance in both works, neither tract contains a discussion of Ciceronian rhetorical doctrine or discusses particular figures, the models assuming a basic tripartite division of exordium, narratio, and petitio, with the use of the cursus velox on the Imperial model by the author of the Oculus pastoralis showing he had

${ }^{32}$ Iohannis Viterbiensis, Liber de regimine civitatum, ed. by Gaetano Salvemini, Bibliotheca Iuridica Medii Aevi, 3 vols (Bologna: Piero Virano, I90I), III, 2I 5-80 (p. 2I7).

${ }^{33}$ Iohannis Viterbiensis, Liber, pp. 22I-22. On the speeches see Gianfranco Folena, “Parlamenti” podestarili di Giovanni da Viterbo', Lingua nostra, 20 (1959), 97-105.

${ }^{34}$ Iohannis Viterbiensis, Liber, p. 226: a judge should be 'oratorem bonum, eloquentissimum, maxime si ipse electus [i.e. the podestà] non est bonus contionator' [a good orator and most eloquent, especially if the elected podestà is not a good speechmaker].

35 Tunberg, Oculus pastoralis, p. I35: 'In this small work which I agreed to write, though unwilling, upon request, I will use a clear and simple style since simplicity is the friend of the ignorant lay person and the moderately literate. The tract that follows is written for them should any of them some day be called upon to rule some place or another. From such teachings they can gather with discerning and wise ingegno the means for talking with elegance to subjects and to non-subjects when the occasion arises or the necessity to hold forth demands'. 
clearly undergone dictaminal training and wrote in an elevated rhetorical register. The range of figures he actually used, but did not gloss, is clearly drawn from material contained in both the De inventione and Ad Herennium. ${ }^{36}$ The moralizing maxims concerning the instrumentality of speech, however, are drawn from a range of classical sources including Cicero's De officiis, Sallust's Bellum Catilinae, and Seneca's Controversies, together with biblical and legal sources. ${ }^{37}$ That advice was given in Latin, with some exemplary material in the vernacular, was therefore more a consequence of the intended target audience than any perceived inability on the part of the reader to deal with basic Latin texts.

Significantly, it was in Bologna that the complex interrelation between feudal and communal rhetorical practice was played out, as the notarial class was introduced more fully to classical rhetorical doctrine. In this respect the works of Guido Fava (c. II9O-c. I245), the Bolognese schoolmaster and teacher of the ars dictaminis, mark a distinct opening out and re-orientation in terms of transmission and education in matters rhetorical for communal speechmakers. ${ }^{38}$ From his comments in the prologue to the Rota nova (c. I226) we know that Fava trained for two years as a lawyer before returning to the study and teaching of rhetoric within the liberal arts programme. ${ }^{39}$ His disdain for law, and love of rhetoric and the commune, stand in marked contrast to Boncompagno's feudal and chivalric social elitism, reflecting the established distinction between the communally engaged notarial class and the politically haughty judicial sector within medieval Bologna. ${ }^{40}$ Similarly, his focus on the functioning of communal government rather than podestarial rule placed him very much on the popular and commercial side of the 'feudo-bourgeois' split which characterized the composition of most communes in the mid-Duecento. ${ }^{4 \mathrm{I}}$ Fava's works were clearly directed to the needs of the busy notary and those involved in the everyday business

${ }^{36}$ See Tunberg, Oculus pastoralis, pp. 73-97, for a detailed discussion of prose rhythm and other stylistic features in the tract. Significantly, many of the figures used are identical with those listed some hundred years later by the anonymous author of the Trattatello di colori rettorici (c. I329-45).

37 On Giovanni's sources see G. Salvemini, 'Il Liber de regimine civitatum di Giovanni di Viterbo', Giornale di storia della letteratura italiana, 4I (I903), 284-303.

${ }^{38}$ On the origins of the notarial schools in Bologna in the first half of the thirteenth century see Gianfranco Orlandelli, 'La Scuola Bolognese di notariato', in Notariato medievale bolognese, Atti di un convegno, Consiglio Nazionale del Notariato, Rome, febbraio 1976, 2 vols (Spoleto: Panetto e Petrelli, I977), I, $28-46$. On the relation of the notarial class to the communal sphere in Bologna, see Gina Fasoli, 'Il notaio nella vita cittadina Bolognese (secc. XII-XV)', in Notariato medievale bolognese, I, I2I-42.

39 See Ernst H. Kantorowicz, 'An “Autobiography” of Guido Faba', Mediaeval and Renaissance Studies, I (I943), 253-80 and A. P. Campbell, 'The Perfection of Ars dictaminis in Guido Faba', Revue de l'Université d'Ottawa, 39 (I969), 315-2I.

$4^{\circ}$ On the differing social positionings of Boncompagno and Fava see Massimo Giansante, 'Guido Fava, Boncompagno da Signa e il comune di Bologna. Cultura retorica e istituzioni nella prima metà del Duecento', in 'Politica e "Studium": nuove prospettive e ricerche', Studi e memorie per la storia dell'Università di Bologna, Io (2005), 47-59. On the politics of the Bolognese notariate see G. Tamba, 'Il notariato a Bologna nell'età di Federico II', in Federico II e Bologna, atti del convegno di Bologna, I 8 marzo 1995 (Bologna: Deputazione di storia patria per le provincie Romagna, I996), pp. 85-105 and Massimo Giansante, Retorica e politica nel Duecento: i notai bolognesi e l'ideologia comunale (Rome: Istituto storico italiano per il Medio Evo, I998), pp. $5-20$.

${ }^{4}$ The term is drawn from Philip Jones, The Italian City-State: From Commune to Signoria (Oxford: Clarendon Press, 1997), p. 290. 
of communal administration. ${ }^{42}$ Above all they were designed to be accessible. Within his corpus there is a notable shift towards providing guidance in the vernacular and directly addressing the subject of civic speechmaking between the r220s and the late I23os and $40 .^{43}$ In his Parlamenti ed epistole (I242-43), which drew on the earlier Oculus pastoralis, Fava differentiates between the written and spoken word by providing his spoken exemplary material in the vernacular and his written examples in Latin. ${ }^{44}$ In his briefer Gemma purpurea (I239-50) he also translated his Latin examples of letter openings into the vernacular.

This form of co-mixing and vernacular interpolation within Latin works was typical of the earliest stages of volgare prose composition and was also replicated in the vernacular interlinear glosses made in medieval grammar school books. ${ }^{45}$ The model orations found in Fava's Arenghe of I240-4I were all still in Latin and, being made up largely of exordia, constituted the oratorical equivalent of exemplary dictaminal salutations rather than full-blown speeches. This is in keeping with the technical definition of the 'arenga' within the ars dictaminis as a modified form of exordium which replaces third-person address with the more direct and emphatic first-person voice, the harangue. ${ }^{46}$ What is noteworthy, however, is that Fava reworked both the Parlamenti et epistole and the Arenghe, and in the second wholly vernacular versions sought to reduce the complexity of dictaminal instruction and increase the imitative component. ${ }^{47}$ Significantly, the target audience is still predominantly

${ }^{42}$ On the growing interdependence in Bologna during the I 240 s and 50 s between the societates populi and the societas notariorum see Roberto Ferrara, "Licentia exercendi” ed esame notariato a Bologna nel secolo XIII', in Notariato medievale bolognese, I, 90-93. For the further consolidation of this nexus later in the Duecento see B. R. Carniello, 'The Rise of an Administrative Elite in Medieval Bologna: Notaries and Popular Government, I282-I292', Journal of Medieval History, 28 (2002), 319-47.

${ }^{43}$ See Charles B. Faulhaber, 'The Summa dictaminis of Guido Faba', in Medieval Eloquence: Studies in the Theory and Practice of Medieval Rhetoric, ed. by James J. Murphy (Berkeley: University of California Press, I978), pp. 85-III.

${ }^{44}$ See 'Parlamenti ed epistole di Maestro Guido Fava', partially edited in Augusto Gaudenzi, I suoni, le forme e le parole dell'odierno dialetto della città di Bologna (Turin: Ermanno Loescher, I889), pp. I27-60. The majority of the examples cited are exordia rather than full-blown speeches or letters. For an edition of the vernacular model letters in the Gemma purpurea see Arrigo Castellani, 'Le formule volgari di Guido Faba', Studi di filologia italiana, I3 (1955), 5-78, (pp. 45-69). On Fava and exordia see Virgilio Pini, 'La Summa de vitiis et virtutibus di Guido Faba', Quadrivium, I (I956), 4I-I52; and more generally, on the flourishing of the exordium within the communal urban context in Italy, see Vittorio Russo, "Exordio" e/o "Proemio" nelle retoriche "volgari" e in Dante', in Strategie del testo: preliminari, partizioni, pause. Atti del XVI e del XVII convegno interuniversitario (Bressanone, I988 e I989) (Padua: Esedra editrice, I995), pp. III-29.

${ }^{45}$ See Black, Humanism and Education on vernacular interlinear glossing of grammar school books, pp. 98I 24 .

${ }^{46}$ On the 'arenga' as a form of exordium see Milner, 'Communication, Consensus and Conflict', p. 430, n. 60. See Guido Faba, Arenghe, British Library, MS Additional Manuscripts, 3322I, fols $44^{\mathrm{r}}-53^{\mathrm{r}}$, and G. Vecchi, 'Le Arenge di Guido Faba e l'eloquenza d'arte civile e politica duecentesca', Quadrivium, 4 (I960), 6I-90. For the text of the Incipit doctrina ad inveniendas incipiendas et formandas materias et ad ea que circa huiusmodi requiruntur see Rockinger, Briefsteller und Formelbücher, pp. 185-96. For the legal use of the term 'arenga' as notarial signing in contract rogation see Ugo Bruschi, 'Nella fucina dei notaia': l'ars notaria tra scienza e prassi a Bologna e in Romagna (fine XII-metà XIII secolo) (Bologna: Bononia University Press, 2006), pp. 229-33.

47 For the vernacular translations see Florence, Biblioteca Medicea Laurenziana, MS Plut. 76.74 , fols. II $8^{\mathrm{v}}-4 \mathrm{O}^{\mathrm{r}}$ : 'Questa e la soma del maestro ghuido fava di lucha sopra laringhare seghondo larte che per lui e fatta e chontiene', and Florence, Biblioteca Nazionale Centrale (henceforth BNCF), MS Fondo Principale II.II.72, fols I $58^{\mathrm{r}}-70^{\mathrm{r}}$ : 'Questi sono Exordi del maestro guido fava darezzo'. See also Faulhaber, 'The Summa dictaminis', p. 9 I. 
podestà or clerics involved in the ritual addressing of formal assemblies, or the kind of diplomatic exchanges that took place between neighbouring podestà concerning jurisdictional disputes or the pursuit of offenders. The speakers, whether lay or religious, still came from those social constituencies expected to possess a degree of facility in the use of Latin: judges, podestà, students, clerics, and ambassadors, although other models address the private realm of social relations between friends, neighbours, and loved ones. There is little evidence in Fava's corpus that those involved in deliberative rhetoric within the commune were perceived as a target audience for his instruction.

Yet what is significant is the changing prosopography of the medieval podestarial elite in central Italy during the Duecento that charts the incremental transition of the 'comune nobiliare' to the 'comune popolare' and the role of the notaries in serving this growing constituency. The marked expansion in the number of citizens appointed to such posts between I250 and I270, particularly from Bologna - a trend also found in other centres such as Modena, the Papal States, and the region of Tuscany - was followed by a further marked surge in the last decade of the Duecento and first decades of the Trecento. ${ }^{4}$ Three hundred and sixty-nine Florentines, for example, were appointed podestà between I28I and I3IO, with only sixty-five individuals registered as judges in the Florentine Guild of Judges and Notaries at the end of the thirteenth century. ${ }^{49}$ Although still a relatively small group, the marked shift between the middle and late Duecento from a Bolognese to a Tuscan/Florentine predominance in the appointment of such judicial officials, and a significant numerical increase, which accelerated even further with the expansion and consolidation of the territorial state towards the end of the century, would seem to complement the shift from Latin to the vernacular in terms of furnishing rhetorical guidance. ${ }^{50}$ Consequently, whilst the Bolognese tradition seems to have given instruction in Latin and examples increasingly in the vernacular, beyond the rarefied realm of formal instruction the Florentine, and more broadly Tuscan, tradition was, as we shall see, wholly vernacular.

\section{Bilingualism in Bologna: from university to commune}

Already in the final two decades of the thirteenth century there was a softening of attitude towards speechmaking on the part of the legal sector in Bologna and something of a rapprochement, given the rhetorical needs of the commune. This is most clearly apparent in the works of Jacques de Dinant, the first documented teacher to combine instruction in ars dictaminis with lectures on the Ad Herennium. Jacques taught rhetoric at the Studio in Bologna post-I260 and may well have been

\footnotetext{
$4^{8}$ See Jean-Louis Gaulin, 'Ufficiali forestieri Bolonais: itinéraires, origines et carrières', and Andrea Zorzi, 'I rettori di Firenze: reclutamento, flussi, scambi (II93-I3I3)', both in I podestà dell'Italia comunale, ed. by Jean-Claude Maire Vigueur, 2 vols (Rome: École Française de Rome, 2000), II, 3II-48 and 453-594.

49 See the detailed statistical analyis in I podestà dell'Italia comunale, II, III8-25.

${ }^{50}$ In addition to the activity of communal orators and ambassadors, the political and juridical arm of the Florentine territorial state numbered over one hundred 'podesterie' by I4I5, twelve so-called 'maggiori', and eighty-eight of 'secondo grado'. See Guidobaldo Guidi, Il governo della città-repubblica di Firenze del primo Quattrocento, 3 vols (Florence: Olschki, I98I), III, I79-239.
} 
the first communally hired teacher of the subject, being formally appointed in I29I. ${ }^{5 \mathrm{I}}$ This practice of combining dictaminal and rhetorical instruction for a communal constituency subsequently endured unbroken in Bologna until the late Trecento and ran parallel to the training offered at the higher level to lawyers and trainee judges. Hence Jacques de Dinant produced a commentary on the Ad Herennium when teaching topical invention and dialectic to lawyers at the university level whilst his Ars arengandi, a paraphrase of the same text orientated towards public speaking, was in all probability offered in conjunction with instruction in the ars dictaminis. ${ }^{52}$ This was the first paraphrase of the Ad Herennium that applied oratorical precepts to contexts that were not solely judicial in orientation. Consequently he refers indiscriminately to his intended speaker as an 'arengator', 'oratore', 'concionatore', and/or 'advocatus'. The material selected from the Ad Herennium is drawn from the first seventeen chapters of Book I, selected chapters of Book 3 on disposition, memory, and pronunciation, and chapters seventeen and eighteen of Book 4 on elocution. ${ }^{53}$

Wholly bereft of exemplary material, the tract is brief, heavily abridged, and exclusively in Latin. In many ways it constitutes an oratorical companion piece to the summary of dictaminal precepts found in Jacques' Breviloquium. ${ }^{54}$ Yet whereas the dictaminal theory there was supplemented by the exemplary material furnished in his Summa dictaminis (I282-95) — in much the same way that Fava appended an exclusively illustrative tract, the Dictamina rhetorica, to his more theoretical Summa there is no known exemplary text containing orations to accompany Jacques' Ars arengandi. ${ }^{55}$ Significantly, however, such instruction was contemporaneous with the emergence in Bologna of vernacular collations of exemplary speeches, most notably by the Bolognese notary Matteo dei Libri whose Arringhe of the mid-thirteenth century enjoyed widespread diffusion and adaptation throughout the Trecento and beyond. ${ }^{5}$ Holding firm with his Latin instruction, Jacques notes in his conclusion to the Ars arengandi that access to the Latin doctrine contained in the text was possible for the less literate with a bit of application and study: 'Notandum autem quod arengator vulgaris omnia predicta potest habere suo modo quodammodo et litteraliter, quod per singula perscrutandi patet ad sensum subtiliter intuenti' [It should, however, be noted that in his own way the vernacular public speaker can make use of all of the preceding [instructions] to some degree and to the letter, as by

${ }^{5}$ I See Guido Zaccagnini, 'Giovanni di Buonandrea dettatore e rimatore e altri grammatici e dottori in arti dello studio Bolognese', Studi e memorie per la storia dell'Università di Bologna, 5 (I920), I98-99, for the communal petition dated 5 July I29I for the hiring of 'magister Iacobus loydiensis diocesis' as professor of rhetoric. Although this document was cited by James R. Banker, 'The Ars dictaminis and Rhetorical Textbooks at the Bolognese University in the Fourteenth Century', Medievalia et Humanistica, 5 (I974), I53-68 (p. I55), the identification of 'magister Iacobus' with Jacques di Dinant was made by Gian Carlo Alessio, 'Il commento di Jacques de Dinant alla Rhetorica ad Herennium', Studi Medievali, 25 (I994), 853-94.

${ }^{52}$ For Jacques' legal commentary on the Ad Herennium see Alessio, 'Il commento'. The Ars arengandi is edited as 'L'Ars arengandi de Jacques de Dinant avec un appendice sur ses ouvrages De dictamine', in Analecta Reginensia. Extraits des manuscrits latins de la reine Christine conserves au Vatican, ed. by André Wilmart (Vatican City: Biblioteca Apostolica Vaticana, I933), pp. II3-5I.

${ }^{53}$ See 'L'Ars arengandi', ed. by Wilmart, p. II4, n. I and Ward, Ciceronian Rhetoric, pp. I74-79.

${ }^{54}$ See the edition of the Breviloquium in 'L'Ars arengandi', ed. by Wilmart, pp. I39-45.

${ }^{55}$ See Guido Faba, Dictamina rhetorica. Epistole, ed. by A. Gaudenzi (ristampa anastatica: Bologna: Forni editore, I97I).

${ }^{56}$ See the edition Matteo dei Libri, Arringhe, ed. by Eleonora Vincenti (Milan: Ricciardi, 1974) and Paul Oskar Kristeller, 'Matteo de' Libri, Bolognese Notary of the Thirteenth Century and his Artes dictaminis', Fontes Ambrosiani, 26 (I95I), 283-320. 
considering each item in turn a more subtle understanding will come about]. ${ }^{57}$ When the vernacular finally found its way into rhetorical instruction in the Studio at Bologna in the first decades of the Trecento, it followed the same division of labour practised by Fava some seventy years earlier: doctrinal instruction was given in Latin and the exemplary material, whether model letters or orations, in the vernacular.

Jacques de Dinant's successor in the chair of rhetoric at Bologna was Giovanni di Bonandrea, whose Brevis introductio ad dictamen ( $1303-04$ ) would become the standard dictaminal text for over a century..$^{58}$ Like Jacques, Bonandrea also lectured publicly on the Ad Herennium, and although no manuscript of his lectures has yet been found, it is most likely that he too focused upon the same sections of the Ad Herennium as Dinant's Ars arengandi. Bonandrea's communal appointment as a teacher of rhetoric at the notarial level and as overseer of the communal chancery marks both a significant broadening of the audiences for rhetorical instruction and the institutionalization of the link established under Fava between the city's notariate and the communal government some fifty years previously. ${ }^{59}$ The increased access to, and dissemination of, rhetorical know-how in Bonandrea's text moved such expertise beyond the judicial elite and applied it more generally to dictaminal and oratorical instruction for trainee notaries and merchants, and laymen. This is reflected in the fact that Bonandrea's lectures on the ars dictaminis and the ars oratoria were open to the public and were held in the civic piazza, the instruction in public speaking being given in the vernacular. ${ }^{60}$

According to documents published by Orioli and cited by Banker, when Bartolino de Benincasa de Canulo assumed responsibility for teaching Giovanni di Bonandrea's Brevis introductio ad dictamen in the Palace of Notaries in the centre of the city in I32I (a course which apparently included instruction in the ars oratoria), Bartolino changed Bonandrea's exemplary civic orations from Latin to the volgare, thereby combining Latin doctrinal instruction with vernacular exemplification. ${ }^{6 \mathrm{I}}$ The existence of a vernacular rendition of Bonandrea's dictamina with marginal commentary dateable to the period I352-85 suggests a market for such instruction in the vernacular existed well into the second half of the Trecento, although it contains no evidence of instruction in oratory, sticking closely to the epistolary rubrics of the original text. $^{62}$

57 'L'Ars arengandi', ed. by Wilmart, p. 135 .

${ }^{58}$ Iohannis Bonandree, Brevis introductio ad dictamen, ed. by Silvana Arcuti (Lecce: Congedo editore, I993).

59 This is the principle thesis of James R. Banker, 'Giovanni di Bonandrea and Civic Values in the Context of the Italian Rhetorical Tradition', Manuscripta, I8 (I974), 3-20, which builds upon Vecchi's observations concerning the widening social constituency addressed by Bolognese dictamina in the Duecento and early Trecento. See Giuseppe Vecchi, Il magistero delle 'artes' latine a Bologna nel Medioevo (Bologna: Patron, I958), pp. 20-2I.

${ }^{60}$ Banker, 'Giovanni di Bonandrea' asserts: 'His instruction in ars dictaminis was given in a public piazza and included the instruction of oral discourse in the volgare' (p. го).

${ }^{6 \mathrm{I}}$ Emilio Orioli, La cancelleria popolesca: atti e formule (Bologna: Emiliano, I9Io), Appendix II, pp. 65-67 (p. 66), I4 October I32I.

${ }^{62}$ See Florence, Biblioteca Riccardiana, MS 2323, fols $\mathrm{I}^{\mathrm{r}}-\mathrm{I} 8^{\mathrm{v}}$ : 'Brieve introductione a dittare'. There are no manuscript attestations of this text in the numerous Florentine rhetorical miscellanies of the Quattrocento which privilege oral over epistolary doctrine. On the decline of the ars dictaminis in this period see the special issue of Rhetorica, I9 (200I), especially Gian Carlo Alessio, 'L'ars dictaminis nel Quattrocento italiano: eclissi o persistenza?', pp. $155-74$. 
This parallel instruction in speaking and writing was replicated in the case of Pietro de' Boattieri (c. I260-I335), who offered courses in Bologna in the ars notaria and the ars dictaminis from the early I290s and also held communal office within the city. ${ }^{63}$ In $\mathrm{I} 32 \mathrm{I}$ his students petitioned the commune, asking that he be required to produce more copies of his textbooks, including a tract on public speaking which combined Latin and vernacular instruction. ${ }^{64}$ From the evidence contained in the sole surviving manuscript of what appear to be student notes taken during Boattieri's teaching of the ars dictaminis, his method seems to have involved taking a mixture of real and fictional letters in Latin, combined with others derived from earlier collations, and paraphrasing them before translating them into the vernacular as an exercise in composing in the volgare. ${ }^{65}$ It is unclear how this worked in terms of teaching public speaking, as sadly there is no information regarding the sources of Boattieri's or Bonandrea's exemplary Latin orations. It is unlikely, however, that they were very different from the kind found in the podestà literature and Fava's Arenghe and Parlamenti ed epistole of the I230s and I240s. Unlike classical rhetorical theory, it is highly unlikely that they were derived from classical sources despite the fact that several of Cicero's orations were known at this time.

The emerging bilingualism in Bologna was driven by the need to address vernacularspeaking audiences and a growing body of non-Latin literate communal officials and office holders. Significantly, when the statutes of the Bolognese guild of notaries were updated in 1246 they required that members should be able to read and write in both Italian and Latin and know how to compose prose writings in Latin according to the rules of dictamen. ${ }^{66}$ In order to test these skills, notaries had to undergo an examination, part of which required them to read and write texts in the vernacular, for ease of comprehension, prior to rendering the same texts in Latin. ${ }^{67}$ This competency is reiterated in a communal provision of 1335 concerning the election and duties of the officials of the city's chancery. One of their duties was to keep copies of all letters sent to, and sent by, the commune and to open and read out letters in either Latin or

${ }^{63}$ See Guido Zaccagnini, 'Le epistole in Latino e in volgare di Pietro de' Boattieri', Studi e memorie per la storia dell'Università di Bologna, 8 (I924), 213-48. Boattieri served on the Consiglio del popolo when Bonandrea was hired in a consultative capacity to help the city's chancery. He was also one of the elders who drew up the 'Statuto dei Notari' (p. 217).

${ }^{64}$ The petition is published in Guido Zaccagnini, 'Giovanni di Bonandrea dettatore e rimatore e altri grammatici e dottori in arti dello studio Bolognese', Studi e memorie per la storia dell'Università di Bologna, 5 (I920), I47-204 (pp. I95-96): 'item quemdam composuerit librum super nobilissima dictaminis arte, et eum super modo aringandi tam licteraliter quam vulgariter' [Likewise, he is required to write a book on the most noble art of letter writing, as well as on speechmaking both in Latin and the vernacular].

${ }^{65}$ For the manuscript in question see BNCF, MS Fondo Principale, II.IV.3I2, fols $86^{\mathrm{r}}-9 \mathrm{I} 9 \mathrm{I}^{\mathrm{r}}$. See Zaccagnini, 'Le epistole', p. 244 .

${ }^{66}$ See Helene Wieruszowski, 'Arezzo as a Center of Learning and Letters in the Thirteenth Century', in her Politics and Culture in Medieval Spain and Italy (Rome: Edizioni di storia e letteratura, I97I), pp. 387-474 (p. 427, n. I).

${ }^{67}$ See Statuti di Bologna dall'anno I245 all'anno I267, ed. by Luigi Frati, 3 vols (Bologna: Regia Tipografia, I869-77), II, I85. The Statutes of the Società dei notai of I 288 also provided for the removal of members whose level of education was not up to scratch. See Rubric XVI: 'Quod illitterati et indocti de matricula tollantur' [That those without Latin and the unlearned are withdrawn from the rolls] in the appendix to Giorgio Tamba, 'L'archivio della Società dei Notai', in Notariato medievale bolognese, pp. 223-83 (pp. 257-58). For a detailed discussion of the examination process see Ferrara, "Licentia Exercendi”, pp. IIO-I2. 
the vernacular depending upon the wishes of the capitani and anziani present, suggesting not only that the linguistic competency of communal officeholders varied but that the members of the executive who served them had to be able to make simultaneous translations when required. ${ }^{68}$ A list of those registered with the guild in I 297 records I 306 notaries as active in the city, all of whom, as noted, were required to be proficient in Latin: some three and a half percent of the city's population. That some were only just capable of meeting the criteria laid down in the guild's statutes is apparent from the provision appointing Giovanni di Bonandrea as instructor and overseer of the city's chancery in July I 303 to aid the less literate and less 'industrious' communal clerks and notaries. ${ }^{69}$ Composition in the vernacular, therefore, was clearly part of the chancery's remit.

The combination of basic doctrinal instruction at the dictaminal level and exemplary material for imitation, therefore, provided the foundations for the teaching of oratorical know-how to the class of trainee notaries and those destined for minor executive and governmental roles, as well as for lawyers arguing in law courts. The public lectures at the Palace of Notaries were clearly intended for those pursuing the shorter notarial and dictaminal courses, although law students were also able to attend. The combining of model vernacular speeches with Latin instruction in classical rhetorical precepts in Bologna illustrates how Latin endured as the language of formal instruction within the city. Such a stance is not surprising within the context of a major university centre whose purpose was to offer instruction in the major discipline areas of the day, especially in law and medicine, fields in which educational precepts were codified and delivered through a well-established Latin-based curriculum. Although the vernacular was the natural language of the citizens of Bologna, the educational lingua franca of the university and its international student body was Latin. Given the absence of any form of vernacular instruction within the university sector, the sole means of accessing rhetorical doctrine in the vernacular was through translations or paraphrases of classical texts. In Bologna, however, there is no evidence to date that vernacular doctrinal instruction on classical rhetorical theory ever took place. Indeed, as a city one could argue that it was characterized by an unusually high level of Latin literacy and its function as training centre for the executive and professional classes created a form of inertia when it came to addressing the rhetorical needs of a moderately or non-Latin literate lay constituency.

\section{Politically speaking: faction and rhetoric}

Such constraints did not apply further afield in the central part of Italy populated by the city-states. Significantly, the political upheavals and regime changes which characterized communal politics in Italy in the I260s were accompanied by the emergence of a number of vernacular commentaries on both the Rhetorica nova and

\footnotetext{
${ }^{68}$ See Orioli, La cancelleria, Appendix III, pp. 67-70 (p. 69).

69 Orioli, La cancelleria, Appendix I, pp. 63-64 (p. 63). Such a constituency had already been identified in the I288 Statutes (see above, n. 42). The figure of I 306 registered notaries in 1297 compares with the 278 registered in I2I9. More particularly, 500 new notaries matriculated between I24I and I250; I000 between I25I and I265, and another 850 between I266 and I273, in total some 2500 over a thirty-five year period. See Ferrara, “"Licentia Exercendi”', pp. 56, II3.
} 
the Rhetorica vetus which differentiate even more clearly between a number of target audiences and their respective needs, implicating rhetorical doctrine in the political struggle for supremacy which was waged between the ever-shifting Guelf/Ghibelline, popular/elite groupings. The vernacular commentaries of the I260s by Brunetto Latini, Bono Giamboni, and Guidotto da Bologna, together with the later midTrecento Trattatello di colori rettorici and Avvenga Dio paraphrase of the Ad Herennium, translated classical rhetorical doctrine to a non-Latin literate readership. All three of the translator/compilers of the I260s wrote out of direct political engagement, fusing juridical and political concerns as judges, notaries, and teachers in a highly politicized way. Latini's Trésor of the I260s and Guidotto da Bologna's partial reworking of the Fiore di rettorica undertaken between I 258 and I 266 can be read as two sides of the same rhetorical coin: one addressing his tract to Charles of Anjou, the other to Manfred of Sicily. Nominal heads of the rival Guelf and Ghibelline movements in Tuscany during the political struggles of the $1250-70$, this politicization of the Tuscan vernacular rhetorical tradition is noteworthy, suggesting the articulation of a Guelph and Ghibelline medieval Ciceronianism. Latini later became notary to Charles of Anjou's vicar in Tuscany, whilst Manfred had studied law in Bologna and furnished imperial troops to the Sienese when they defeated the Florentines at the Battle of Montaperti in I260, his vicar Count Guido Novello becoming podestà of Florence as the city lost its communal government.

Guidotto's identity has been the subject of some debate, but recently the probability of his being a teacher of grammar, rhetoric, 'et perorationibus, sive arengis' at the Studio in Siena in the I270s has gained ground and would certainly cohere with his dedication and stance within his reworking of Bono Giamboni's earlier paraphrase of the Ad Herennium, the Fiore di rettorica. Guidotto's chivalric podestarial bias is apparent in his description of Cicero as a latterday knight, 'amabile e costante, formato di grazia e di vertudi, grande di persona, e ben fatto di tutte membra; e fue d'arme maraviglioso cavaliere, franco di coraggio, armato di grande senno, fornito di scienzia e di discrezione, ritrovatore di tutte cose'. ${ }^{70}$ Guidotto's identification of the situations and uses to which such rhetorical know-how could be put also aligns his presentation of the tract with an elite class of rulers, knights, magistrates, and itinerant judicial officials, the science of 'la bisogna di tutto giorno parlare' being appropriate for a range of scenarios:

Sì come in fare leggi e piati civili e criminali, e ne le cose cittadine, sì come in fare battaglie e ordinare schiere e confortare cavalieri, ne le vicende de l'imperii e regni e principati, in governare popoli e regni e cittadi e ville strane e diverse genti, siccome conversano nel grande cerchio del mappamundo de la terra. ${ }^{7 \mathrm{I}}$

There is little sense of rhetorical education for the lay citizenry here. In fact Guidotto literally re-presents Bono Giamboni's translation through a modified dedication as an amplified advice book in the 'tradition' of podestà literature addressed to the high caste chivalric pro-Imperial, and in this instance, philo-Ghibelline podestà.

Giamboni's original redactions, by contrast, addressed the participants within the communal political sphere itself rather than those charged with overseeing it.

\footnotetext{
${ }^{70}$ Speroni, Fiore, redaction $\delta$, p. I49.

${ }^{71}$ Speroni, Fiore, redaction $\delta$, p. I 48 .
} 
Giamboni also had a judicial background and served most of his time as a judge, 'iudex', and procurator within Florence. Although cited as pro-Ghibelline on account of his remaining in Florence throughout the exile of Latini and other leading Guelfs, the key point is that as a judge and a Florentine he served the popular commune. ${ }^{72}$ In the first chapter he mentions how the ability to speak, 'favellare', when combined with justice and wisdom, 'con la giustizia e col senno', is 'molto utile e caro al suo commune, e agli amici e parenti grandisimo consiglio e refuggio'. ${ }^{73}$ Significantly, Giamboni asserts that 'laymen', or what he terms 'laici', were accustomed to refine their speaking skills through applied exercise and imitation of good practice rather than through knowledge of classical rhetorical doctrine per se. Although Giamboni's comments are merely an expansion of the opening sections of the Ad Herennium, the crucial innovation lies in his introduction of a differentiation between those capable of operating in Latin and those laymen whose only access to such precepts was through vernacular translations and collations of rhetorical teachings:

E per li due modi che sono posti prima di sopra - cioè o per usanza di molto dire, o per seguitare nel suo dire alcuno bello dicitore - apparano gl'uomini laici a parlare, e non per lo terzo, cioè per sapere la dottrina che 'n sul favellare è data da' savi, perché nolla sanno né possono sapere, perch'è e data per lettera da loro.

$\mathrm{Ma}$, acciò che di questa via possano i laici alcuna cosa sentire, mi penerò di darne in volgare alcuna dottrina, avegna che malagevolemente si possa fare, perché la materia è molto sottile, e le sottili cose non si possono bene aprire in volgare, sì che se n'abbia pieno intendimento. ${ }^{74}$

Giamboni's abridged translation subsequently seeks to remedy this difficulty by providing access to rhetorical doctrine in the vernacular for participants in communal councils. This is reflected in the fact that the major elaboration and digression from the Ad Herennium in Giamboni's Fiore relates to an extensive consideration of the diverse forms of deliberative civic counsel: 'Come il dicitore dee sapere ben consigliare in su le cose', 'Della dottrina per quante vie e modi si può consigliare in su le cose', 'Come si dé consigliare quando l'utilità de la cosa sopra la quale si piglia consiglio è che stia bene e dirittamente'. ${ }^{75}$

The same impulse to educate a communal lay constituency also lies at the heart of Latini's rhetorical works, albeit with a much more specific political agenda. Undoubtedly conditioned by his exile post-I260, Latini's popular Guelfism and clear antipathy towards the chivalric milites and pro-Ghibelline elite saw him appropriate Ciceronian rhetoric as the ideology of the popular commune and as the vehicle for stigmatizing the aristocratic magnates who refused to work with the popular guildbased government of the popolo. By superimposing the historical events surrounding the Catilinarian conspiracy as derived from Sallust onto the rhetorical doctrine furnished by Cicero, Latini constructed a rhetorical paradigm that defined the limits

\footnotetext{
${ }^{72}$ See S. Foà, 'Giamboni, Bono', in Dizionario biografico degli italiani, LIV (2000), 302-04.

73 Speroni, Fiore, redaction $\beta$, p. 4.

${ }^{74}$ Speroni, Fiore, redaction $\beta$, p. 5 .

${ }^{75}$ Speroni, Fiore, pp. cclxii-xv and redaction $\beta$, chapters $73-80$, pp. 83-95.
} 
of communal participatory politics. ${ }^{76}$ Central to this programme was the necessity, rather than desirability, that fellow laymen mastered speech as an art in the same way as they mastered other 'artes' within their respective guilds. Consequently, applied learning combined with discipline was required to ensure such competency, imitation and models alone being insufficient in securing understanding. As he states in the vernacular version of the Trésor:

Dunque è provato, che la scienza della retorica non è in tutto acquistata per natura e per uso, ma per insegnamento e per arte. E per ciò dico, che ciascuno uomo dee istudiare, e mettere il suo intelletto e 'l suo ingegno a saperla. ${ }^{77}$

Addressed to Charles, Count of Anjou, in his guise as Papal champion in Italy against Manfred, the hybrid nature of the third book of Latini's Trésor sees the podestarial advice on government, which is largely Aristotelian and derived from both the Oculus pastoralis and Giovanni da Viterbo's Liber de regimine civitatum, bolted onto his treatment of the six parts of rhetorical invention drawn from Cicero's rhetorical works. ${ }^{78}$ This first section, which goes under the title 'Li livres de bone parleure', builds upon his partial commentary on Cicero's De inventione entitled La rettorica (c. I260-66) in discussing in turn the exordium, narratio, partitio, confirmatio, reprehensio, and conclusio. ${ }^{79}$ In this earlier tract, Latini notes that his work was undertaken on the entreaty of a fellow Guelf exile and Florentine friend who 'era parlatore molto buono naturalmente, e molto disiderava di sapere ciò che' savi aveano detto intorno alla retorica'. ${ }^{80}$ Being a 'buono intenditore di lettera' and 'molto intento allo studio di rettorica', Latini undertook the task, adding a vernacular commentary to Cicero's translated text 'per maggiore fermezza' and casting himself as commentator or 'sponitore'. The role and intent of this 'sponitore' is clearly defined by Latini:

il quale mise tutto suo studio e suo intendimento ad isponere e chiarire ciò che Tulio avea detto; et esso è quella persona cui questo libro appella sponitore, cioè ched ispone e fae intendere, per lo suo proprio detto e de' filosofi e maestri che sono passati, il libro di tulio, e tanto più quanto all'arte bisogna di quel che fue intralasciato nel libro di tulio, sì come il buono intenditore potràe intendere avanti. ${ }^{{ }^{1}}$

The need to be thorough in explication is reemphasized: 'perciò che llo sponitore non vuole lasciare un solo motto donde non dica tutto lo 'ntendimento'. ${ }^{82}$ Latini fails to get beyond Cicero's discussion of exordia before the tract breaks off, but it is as

${ }^{76}$ See Stephen J. Milner, 'Exile, Rhetoric, and the Limits of Civic Republican Discourse', in At the Margins: Minority Groups in Pre-Modern Italy, ed. by Stephen J. Milner (Minneapolis: University of Minnesota Press, 2005), pp. I62-91.

${ }^{77}$ Il 'Tesoro' di Brunetto Latini volgarizzato da Bono Giamboni, ed. by Luigi Gaiter, 4 vols (Bologna: Gaetano Romagnoli, I878-83), III, viii, I.

${ }^{78}$ On Latini's sources see Gian Carlo Alessio, 'Brunetto Latini e Cicerone (e i dettatori)', Italia medioevale e umanistica, 22 (1979), I23-69 (pp. I32-59) and Julia Bolton Holloway, Brunetto Latini. An Analytic Bibliography (London: Grant and Cutler, I986), pp. 87-105.

${ }^{79}$ On Latini's association with Charles of Anjou and his notarial activity with the Florentine Guelf exiles, see Julia Bolton Holloway, Twice-Told Tales: Brunetto Latino and Dante Alighieri (New York: Peter Lang, I993), pp. $5 \mathrm{I}-73$.

${ }^{80}$ See Brunetto Latini, La rettorica, ed. by Francesco Maggini (Florence: Le Monnier, I968), p. 7 .

${ }^{8 \mathrm{I}}$ La rettorica, p. 6.

${ }^{82}$ La rettorica, p. I3. 
close as we get to a vernacular ars aringandi and is produced outside the formal instructional context of Bologna. Although Latini acknowledges the scribal dictaminal tradition and the realms of consolation literature and personal correspondence, the overriding emphasis is on the controversial realm of communal deliberation and argumentation, his wholesale acceptance of the prescriptive Ciceronian definition of the proper scope of rhetoric returning the art to the exclusively political sphere of situated disputation, and, what is more, disputation undertaken orally. ${ }^{83}$ This exclusive focus on rhetorical invention as an applied art addressing verbal 'lite' within the legitimating frameworks of communal government as an alternative to armed 'lite' carried out in the city's streets was central to his political aim of rendering 'civil' the clans of the Florentine chivalric dynasties. In the first half of Book 3 of the Trésor, however, the orientation of the work towards a podestarial rather than communal reader sees the reintroduction of the dictaminal element, the clarification of the differentiation between speech and writing, and the furnishing of complete exemplary speeches from Sallust's Bellum Catilinae to emphasize both the civic morality and the centrality of deliberation to Florentine communal politics. ${ }^{84}$ The extraordinary vernacular rhetorical explosion of the I26os, therefore, can be allied to the momentous socio-political changes which took place within the communes, and especially within Florence, as popular guild-based regimes literally found their voice and appropriated a larger share of the governmental process away from the traditional ruling elite of noble dynasties.

\section{The final flowering: rhetoric wholesale}

By the Trecento and with the victory of the popolo, vernacular rhetorical doctrine addressed active citizens rather than executive and judicial overlords, with education through emulation prevailing over doctrinal instruction. This is the position assumed by both of the other vernacular abridgements of the Ad Herennium, the Avvenga Dio paraphrase and the Trattatello di colori rettorici, an abridgement of parts of Books 3 and 4 of the Ad Herennium, composed c. I329-45. In both texts it is clear that theoretical instruction was intended to refine existing speechmaking practices in much the same way as we still learn to speak before we learn the formal rules of grammar, art building upon the natural gift of speech. The opening of the Trattatello di colori rettorici, certainly suggests as much. The adaptor/translator notes his intention 'brievemente volando' to explain the principal figures of speech 'i quali li uomini continuamente usano ne'.lloro parlari, avenga che.lla minore parte per dotrina li conoschino'. ${ }^{85}$ In translating a selection of figures into the vernacular, the translator is making explicit in doctrinal terms figures which many speakers already used even if unaware of their technical rhetorical status or name. This perspective is further

${ }^{83}$ Although a rather crude measure, this emphasis is reflected in the relative frequency in the text of the verbs 'dire' and 'parlare' and their various inflections and variants relative to 'dittare' and 'scrivere'. See Spogli elettronici dell'italiano delle origini e del Duecento II.3: Brunetto Latini, La rettorica, ed. by Mario Alinei (Bologna: Il Mulino, I97I), pp. 75, 78, I67, 207.

${ }^{84}$ See Li livres dou Trésor de Brunetto Latini, ed. by Francis J. Carmody (Berkeley: University of California Press, I948), pp. 3I 5-90.

${ }_{5}$ Anonymous, Trattatello di colori rettorici (c. I329), ed. by Antonio Scolari; see Scolari, 'Un volgarizzamento trecentesco della Rhetorica ad Herennium: il Trattatello di colori rettorici', Medioevo romanzo, 9 (I984), 2 I5-66 (p. 244). 
emphasized in the translator's assessment of the many subdivisions of rhetoric, which he claims are so numerous that 'pochissimi ne vegnono a perfezione e la magior parte de' moderni rettorici seguitano lo stilo d'alcuno altro eccellente rettorico; e così per uso più che per dottrina úsaro loro rettorica secondo le dette quatro generali divisioni'. ${ }^{86}$

These texts sought to pass on certain 'fiori', or what the author/adapter of the Trattatello terms 'alcuna particella del bello parlare rettorico' or 'favelle', as a consequence of requests received from either friends or patrons desirous for such knowledge and untrained in Latin. Such sentiments are also found in the introduction to the mid-Trecento Avvenga Dio translation. In this instance the introduction runs as follows:

In questo libro si tratta della doctrina e degli amaestramenti che sono dati a dicitori che vogliono sapere bene e piacievolemente parlare. Extracti dalla rettoricha nuova di tulio Romano. Et rechati in cierti ordini Ad istantia di cierti gientili huomini volgari pero che chome a literati e fastidio a leggere stilo volgare. Coxi a volgari huomini e fastidio et increscimento a leggiere overo a udire alchuna doctrina licterale. ${ }^{87}$

As to which fiori of rhetoric were worth picking, which speeches worth translating, and what was 'lost in translation' or considered too 'sottile' for a lay audience, it seems, perhaps unsurprisingly, that the principles of selectivity in terms of transmitting vernacular rhetorical doctrine were actually conditioned by the perceived relevance of the doctrine to the specific situated context of speechmaking. In terms of the selective adaptation and translation of the Ad Herennium, all the Trecento vernacular commentaries focus the majority of their attention on Book I, parts of Book 3, and Book 4. As Speroni has painstakingly charted in relation to both the Fiore di Rettorica and the anonymous Avvenga Dio adaptations, most of the material is derived from Book 4 of the Ad Herennium on the figures of diction, with smaller extracts drawn from the sections in Book I dealing with exordia, sections of Book 3 on delivery and memory, and the opening chapters of the De Inventione. The same pattern applies to the Trattatello di colori rettorici.

As for the material considered too 'sottile' for a lay readership, the majority of passages where the adaptor chose to gloss over aspects of doctrinal instruction relate specifically to legal issues, suggesting that the subject matter rather than linguistic equivalency was the major obstacle in this instance. Hence Giamboni, when he reaches the topic of legal issues and proof, writes:

non dirò alcuna cosa, perché la lor materia è sì grande e distesa e sì sottile e profonda che non si potrebbe buonamente recare in volgare; e quando in volgare si recasse, sarebbe a colui ch'è laico di gran fatica a intendere, e di poca utilitade, ché sono cose che si fanno solamente a coloro che sono avocati. ${ }^{88}$

\footnotetext{
${ }^{86}$ Trattatello di colori rettorici, p. 244 .

${ }^{87}$ Anonymous, Avvenga Dio: mid-Trecento adaptation and translation of the Ad Herennium. BNCF, MS Fondo Principale, II.I.68, fol. $7^{\mathrm{r}}$. See the discussion and extracts from this text, albeit from a different manuscript version, in Virginia Cox, 'Ciceronian Rhetorical Theory in the Volgare: A Fourteenth-Century Text and its Fifteenth-Century Readers', in Rhetoric and Renewal in the Latin West IIOO-I544: Essays in Honour of John O. Ward (Turnhout: Brepols, 2003), pp. 20I-25.

${ }^{88}$ Giamboni, Fiore, redaction $\beta, 64$, pp. 69-70.
} 
In the oldest of the four Fiore redactions, the anonymous author/adaptor takes a similar line in relation to the subject of conclusions, another subject buried in the heart of Book 2 of Ad Herennium, where aspects of forensic rhetoric are still the main subject under consideration:

$\mathrm{E}$ in che modo il dicitore pò far conclusione per via de 'bominamento, inzicando l'animo de l'uditore e acendendolo contra l'aversario suo, e in che modo per via di misericordia, recando a misericordia l'animo de l'uditore verso colu' che favella, no ti vo' qui mostrare e aprire, perché e a me sarebe faticoso a mostrare, e a' laici ad intendere tropo sotile. Però, color che son literati, se de le dete cose voglion sapere, legan ne le Retorica de Tullio, là ove ne troverano pienamente tratato; e i laici faciano questi dui modi de conclusione, che sono le fini e le restate de le dicirie, come s'aconcia per natura lor di fare, secondo la materia ne la qual si favella. ${ }^{89}$

Cuts are made, given the inapplicability of certain aspects of legal argumentation to a lay constituency and in keeping with the observation made by the original author of the Ad Herennium himself, who noted that forensic rhetoric was by far the most difficult of the three forms.

Yet the incremental 'opening' of the full gamut of rhetorical theory into the vernacular is once again attested by the Avvenga Dio translation, which not only deals with sections of Book 2 of the Ad Herennium, but insists vernacular readers persevere where previous commentators had been more lenient. Whilst admitting to the complexity, or 'schurta', of the text, the translator seeks to prise it open (bear in mind the aprire of the opening quotation) with the aid of the illustrative examples and model speeches. Hence in the preamble to an exemplary oration concerning judicial pleading he notes, 'Accio che questo ti sia più aperto, pongoti i detti modi in forma come tu abbia a dire'. ${ }^{90}$ On the subject of confirmation and refutation, notably passed over by Giamboni, as we have seen, he insists that the reader apply himself with 'industria' as 'queste sono le parti nelle quali è tutta la speranza dello dicitore et per le quali porta piena vittoria a suo intendimento'. ${ }^{\text {I }}$ Here, as with Latini's texts, is a translator and adapter facilitating and challenging the understanding of a lay audience in the full belief that speech and its ordered and careful use can secure victory and advancement within agonistic juridical, political, and social contexts. Nevertheless, the translator adds the rider that if the reader has difficulty understanding aspects of the text he should not be embarrassed to seek help from more learned colleagues:

Pero cholui che leggie in questo libro se alchuna cosa dubitasse legga in prima e rilegga molte volte si che dasse medesima lentenda. Et se non lantendessi non si vergogni di ritrovare a savi che glintendano pero che adomandando altri imparra. ${ }^{22}$

The supposition that a vernacular reader would know, or be able to gain access to, such a 'savio', or that the more complex parts of rhetorical doctrine might become conversation pieces, in the vernacular and beyond the classroom or lecture theatre,

\footnotetext{
${ }^{89}$ Giamboni, Fiore, redaction $\alpha, 65$, p. II6.

${ }^{\circ}$ Avvenga Dio, fol. $26^{\text {v }}$.

${ }^{91}$ Avvenga Dio, fol. $\mathrm{I}^{\mathrm{v}}$.

${ }^{2}$ Avvenga Dio, fol. $9^{\mathrm{r}-\mathrm{v}}$.
} 
can be read as an indicator of both the breadth and depth of dissemination. Certainly the numerous Quattrocento miscellanies and zibaldoni that continued to collate vernacular speech material, especially in Florence, would seem to suggest that demand grew rather than abated during the Renaissance, that 'unofficial' vernacular classicism regarding rhetorical material constituted a dynamic and practical dialogue with a republican rhetorical heritage which placed a similar premium on the effective management and deployment of the spoken word. ${ }^{93}$

\section{Conclusion: the rhetorical advent of popular classicism}

In his pioneering study of the changes wrought in the ars dictaminis by the Bolognese dictatore Giovanni di Bonandrea in the late Duecento, James Banker described the process whereby 'communal society insinuated its needs and values into the Italian rhetorical tradition'. ${ }^{94}$ Although Banker's study focused almost exclusively upon the teaching of Latin prose composition in Bologna as contained within the artes dictandi, the same processes of selective adaptation were clearly at work in relation to the vernacular reworking of classical rhetorical theory and the transmission of exemplary material for speechmaking practices throughout the communal period. The demand for such material was obviously driven by its perceived relevance and utility to a community of illetterati. Given their desire to address each other in a variety of civic contexts, Banker's use of the term 'insinuation' is doubly appropriate. The oblique, or indirect, approach to the classical rhetorical corpus, which vernacular translation embodies, allows our understanding of the reception of classical material to be opened out to encompass a whole body of work which has been largely obscured by the Latin-centred accounts of the rhetorical renaissance. As we have seen, this was an incremental process which ran in conjunction with both the increasing participation of citizens in communal government and the increasing propensity for rhetorical self-imagination as political communities from the mid-Duecento to the late Trecento.

Several years ago Ronald Weissman, an historical anthropologist working on Florentine social relations, speculated that it is possible that the importance of classical rhetoric in Renaissance culture had quite popular origins, rooted in the necessary verbal sensitivities required to negotiate the demands of everyday life'.$^{95}$ In the Florentine context, I think it is time to consider revising the parameters of humanism to encompass the encounter of non-Latin literate vernacular readers and speakers with classical texts. Kristeller's identification of the oratorical concern of the dictatores in late medieval Italian culture as one of the points of continuity with Quattrocento humanism needs to be refined to include the lay vernacular reception of what we might term 'popular classicism', understood as a phenomenon which was not a formal art, not a part of an institutionalized curriculum, not even a critical attitude towards textual and linguistic concerns, but rather a means of communal imagination

\footnotetext{
93 Milner, 'Communication, Consensus and Conflict', pp. 395-99.

94 Banker, 'Giovanni di Bonandrea', pp. I-2.

${ }_{95}$ Ronald F. E. Weissman, 'The Importance of Being Ambiguous: Social Relations, Individualism, and Identity in Renaissance Florence', in Urban Life in the Renaissance, ed. by S. Zimmerman and Ronald F. E. Weissman (Newark, DE: University of Delaware Press, I989), pp. 269-80 (p. 273).
} 
and communicative praxis tout court..$^{96}$ The notion that vernacular literacy hindered the development of humanism in Florence can only be questioned by redefining humanism itself, looking at it in broader social terms as the encounter of a public and society at large, in all its forms, with precepts and insights concerning civic life translated from a former age. Within such an alternative narrative, Latin humanism features as a minority enterprise relative to the broader reception history of vernacular classicism in which the volgare consolidated its position as the communal language during the Quattrocento and the medium of pre-modern rhetorical knowledge transfer.

${ }^{96}$ P. O. Kristeller, 'Humanism and Scholasticism in the Italian Renaissance', Byzantion, I7 (I944-45), 346-74, reprinted in Renaissance Thought and Its Sources, ed. by Michael Mooney (New York: Columbia University Press, I979), pp. 83-I05. Kristeller reviewed the reception of his thesis in his piece 'Rhetoric in Medieval and Renaissance Culture', in Renaissance Eloquence: Studies in the Theory and Practice of Renaissance Rhetoric, ed. by James J. Murphy (Berkeley: University of California Press, I983), pp. I-I9. See the essays collected in Cox and Ward, The Rhetoric of Cicero, for a more socially contextualized consideration of the medieval and Renaissance reception of classical rhetorical theory and its intended audiences and users. 